Article

\title{
An Active Gelatin Coating Containing Eugenol and Vacuum Delays the Decay of Chinese Seabass (Lateolabrax maculatus) Fillets during Cold Storage: A Microbiome Perspective
}

\author{
Xuan Ma ${ }^{1,+}$, Qianqian Zhou ${ }^{1,+}$, Weiqiang Qiu ${ }^{1,2,3,4}$, Jun Mei ${ }^{1,2,3,4, *}$ and Jing Xie ${ }^{1,2,3,4, *(\mathbb{C}}$ \\ 1 College of Food Science and Technology, Shanghai Ocean University, Shanghai 201306, China; \\ m190310921@st.shou.edu.cn (X.M.); m170200465@st.shou.edu.cn (Q.Z.); wqqiu@shou.edu.cn (W.Q.) \\ 2 National Experimental Teaching Demonstration, Center for Food Science and Engineering, \\ Shanghai Ocean University, Shanghai 201306, China \\ 3 Shanghai Engineering Research Center of Aquatic Product Processing and Preservation, \\ Shanghai 201306, China \\ 4 Shanghai Professional Technology Service Platform on Cold Chain Equipment Performance and Energy \\ Saving Evaluation, Shanghai 201306, China \\ * Correspondence: jmei@shou.edu.cn (J.M.); jxie@shou.edu.cn (J.X.); \\ Tel.: +86-21-61900349 (J.M.); +86-21-61900351 (J.X.) \\ + Contributed equally as first authors.
}

Citation: Ma, X.; Zhou, Q.; Qiu, W.; Mei, J.; Xie, J. An Active Gelatin Coating Containing Eugenol and Vacuum Delays the Decay of Chinese Seabass (Lateolabrax maculatus) Fillets during Cold Storage: A Microbiome Perspective. Coatings 2021, 11, 147. https://doi.org/10.3390/ coatings11020147

Academic Editor: Maria Jose Fabra Received: 24 December 2020

Accepted: 22 January 2021

Published: 28 January 2021

Publisher's Note: MDPI stays neutral with regard to jurisdictional claims in published maps and institutional affiliations.

Copyright: (c) 2021 by the authors. Licensee MDPI, Basel, Switzerland. This article is an open access article distributed under the terms and conditions of the Creative Commons Attribution (CC BY) license (https:// creativecommons.org/licenses/by/ $4.0 /)$.

\begin{abstract}
The purpose of this study was to evaluate the effect of an active gelatin coating containing eugenol and vacuum on the microbial diversity of Chinese seabass (Lateolabrax maculatus) during cold $\left(-0.9^{\circ} \mathrm{C}\right)$ storage. The bacterial sequences in Chinese seabass were observed using a high-throughput sequencing technique targeting the V3-V4 region of the 16S Ribosomal DNA (rDNA) on 0, 12th, and 24th day, which showed a more comprehensive estimate of the microbial diversity in seabass samples compared with microbial enumeration. The results revealed that the species diversity of fresh seabass was rich, mainly including Carnobacterium, Glutamicibacter, and Pseudomonas, with abundance ratios of $0.286,0.160$, and 0.130 , respectively. Pseudomonas and Shewanella were the primary contaminants in the spoiled control samples, where the abundance ratios increased from 0.220 and 0.174 on the 12th day to 0.802 and 0.163 on the 24th day, respectively. Vacuum treatment could inhibit the growth of Pseudomonas and Shewanella such that when stored on the 12th day, Brochothrix became the superior genus. However, Pseudomonas and Shewanella dominated the storage until the 24th day, where their abundance ratios were 0.343 and 0.279 , respectively. The inhibition of Pseudomonas and Carnobacterium was gradually enhanced with increasing concentrations of eugenol. Furthermore, an active gelatin coating containing eugenol and vacuum treatment was more effective at inhibiting the increase of the total volatile basic nitrogen. This study confirmed that an active gelatin coating containing eugenol and vacuum could reduce the species of bacteria, inhibit the growth and reproduction of the main dominant spoilage bacteria, and delay the spoilage of seabass.
\end{abstract}

Keywords: coating preservation; high-throughput sequencing; shelf life; diversity

\section{Introduction}

Chinese seabass (Lateolabrax maculatus) is one of the most economically significant cultured fish with a high yield in China [1,2]. The seabass has tasty meat and is rich in protein $(21 \%)$ [3,4]. However, fresh seabass is perishable due to the growth of spoilage organisms and endogenous enzymes that promote the hydrolysis of muscle protein [5-7]. Therefore, it is necessary to search for new preservation methods to improve the quality of fresh seabass. Given that the shelf life of vacuum-packaged aquatic products is relatively short because of the activity of spoilage microorganisms, research on new preservation methods that can inhibit the growth of these microorganisms is required [8]. 
Active coatings with antimicrobial properties have been extensively studied and are applied in food preservation to inhibit the growth of microorganisms, thereby extending the shelf life [9-11]. Active coatings are usually composed of polysaccharides, proteins, and lipids, and can act as a carrier for natural antioxidants and antimicrobial agents to improve the quality of fresh food [12-14]. Among biopolymers, proteins possess a good film-forming ability and have been used as edible food packaging materials [15]. In particular, fish gelatin is an excellent material with good film-forming ability and oxygen barrier properties [16].

In recent years, many studies have focused on the properties of fish gelatin films, emphasizing that the properties depend on the species of fish and differ from those of mammals [17]. Since fish gelatin has low or no significant antimicrobial or antioxidant activity, the inclusion of bioactive ingredients into the fish gelatin film, including plant extracts $[18,19]$, essential oils $[20,21]$, and phenolic compounds [22,23], has been explored with satisfactory results [24]. Eugenol (4-allyl-2-methoxyphenol) is the main component in clove oil and is used as a flavoring agent in various food and cosmetic industries. Many studies have shown that eugenol has biological properties, including antioxidant, antimicrobial, and antifungal activities [25,26]. To enhance the antimicrobial activity of gelatin-based films, eugenol has been added. Apart from acting as an antimicrobial agent, eugenol can also serve as a protein cross-linker [27]. High-throughput sequencing technology has been extensively utilized to analyze the microbial diversity and microbial community changes due to its superiority regarding identifying both unculturable microorganisms and low-abundance microorganisms [28]. Total DNA is extracted directly from the test sample for analysis, avoiding traditional methods of microbial isolation and culture [29,30]. At present, the high-throughput sequencing technology has been used in determining the microbial diversity of fish during storage, such as catfish [31], grass carp [32], snakehead [33], silver carp [34], and others [35,36]. Therefore, the high-throughput sequencing technology, combined with a traditional microbial culture method, could help us accurately explore the dominant microorganism at the genus and species levels.

Earlier studies have focused on the effect of active gelatin coatings containing eugenol on the extension of the shelf life of Chinese seabass in terms of their organoleptic properties, chemical analysis, and microbiological enumeration $[37,38]$. However, there is limited information on how active gelatin coatings containing eugenol affects the microbial diversity of vacuum-packaged Chinese seabass, although this knowledge may contribute to the development of eugenol as a preservative. In the current study, we aimed to assess the effect of active gelatin coatings containing eugenol on the bacterial communities and shelf life of vacuum-packaged Chinese seabass fillets stored at $-0.9^{\circ} \mathrm{C}$ in terms of the total volatile basic nitrogen (TVB-N) and spoilage organisms. A combination of high-throughput sequencing and traditional microbial culture method was applied to characterize the variations in bacterial communities and the dominant microbiota in Chinese seabass fillet samples during cold $\left(-0.9^{\circ} \mathrm{C}\right)$ storage.

\section{Materials and Methods}

\subsection{Materials and Reagents}

Chinese seabass with an average weight of $800 \pm 10 \mathrm{~g}$ were purchased from a local market in Luchao Port town (Shanghai, China) and transported to the lab within $1 \mathrm{~h}$. After being treated with crushed ice for $15 \mathrm{~min}$, they were killed and the gills and viscera of the seabass were removed and washed with running tap water.

Food grade gelatin (Bloom value: $240-270), \beta$-cyclodextrin ( $\beta-C D)$, and glycerol were purchased from Sangon Biotech Co., Ltd., Shanghai, China. Eugenol (purity $>98 \%$ ) was purchased from Aladdin Reagent Co., Ltd., Shanghai, China. Plate counting agar was purchased from Haibo Biotechnology Co., Ltd., Qingdao, China. 


\subsection{Preparation of the Active Gelatin-Eugenol Coating Solution}

An active gelatin coating containing eugenol solution was prepared as described by Sun et al. [39] with some modifications. Eugenol $(75,150$, and $300 \mu \mathrm{L})$ and $750 \mathrm{mg}$ $\beta$-cyclodextrin ( $\beta-C D)$ were stirred mechanically once in a beaker. Then, $5 \mathrm{~g}$ Tween 80 was added and $40 \mathrm{~mL}$ ultrapure water was subsequently added to a final emulsion volume of $100 \mathrm{~mL}$ and the dispersion was homogenized with a rotor-stator homogenizer (HR-6, Huxi Industrial Co., Ltd., Shanghai, China) at 15,000 rpm for $5 \mathrm{~min}$. Gelatin $(6.0 \% \mathrm{w} / \mathrm{w}$, Bloom value at $240-270$, BBI Life Science, Shanghai, China) and glycerol $(1.5 \% v / w)$ were dissolved in prepared microencapsulated eugenol emulsions $(3 \mathrm{~L})$ at $50{ }^{\circ} \mathrm{C}$ and stirred at 15,000 rpm for $4 \mathrm{~h}$. Then, the mixture was treated with an ultrasonic homogenizer (XEB-1000-P, Xiecheng Ultrasonic Equipment Co. Ltd., Jining, Shandong, China) at $20 \mathrm{kHz}$ with a power of $800 \mathrm{~W}$ for $10 \mathrm{~min}$ to obtain homogeneous coating solutions containing $0.075 \%, 0.15 \%$, and $0.30 \%$ of eugenol, which were degassed under vacuum.

\subsection{Preparation of the Seabass and Sample Treatments}

The prepared seabass fillet samples were thoroughly washed with sterilized $1 \% \mathrm{NaCl}$ solutions and randomly divided into five batches for: (1) CK (uncoated), (2) VP (vacuum packaged), (3) G-0.075E + VP (coated with the active gelatin coating containing $0.075 \%$ eugenol and vacuum packaged), (4) G-0.15E + VP (coated with the active gelatin coating containing $0.15 \%$ eugenol and vacuum packaged), and (5) G-0.30E + VP (coated with the active gelatin coating containing $0.30 \%$ eugenol and vacuum packaged). Different batches of seabass samples were immersed in the corresponding freshly prepared coating solutions for $10 \mathrm{~min}$ at $4{ }^{\circ} \mathrm{C}$ with a solution ratio of $1: 3(w / v)$; then, the seabass samples were taken out and put into a sterile biochemical incubator with air flow at $4{ }^{\circ} \mathrm{C}$ for $60 \mathrm{~min}$ to form the coating. After that, the seabass fillet samples were packaged individually under a vacuum using 80- $\mu \mathrm{m}$-thick plastic bags (Garcia de Pou, Girona, Spain) and stored at $-0.9 \pm 0.1^{\circ} \mathrm{C}$ in a refrigerator (BPS-250CB, Yiheng Thermostatic Chamber, Shanghai, China). The seabass fillet samples were randomly selected for analysis on days 0,12 , and 24 .

\subsection{Determination of the Total Volatile Basic Nitrogen}

The TVB-N was measured according to the semi-trace Kjeldahl method [40]. Briefly, $5 \mathrm{~g}$ of minced dorsal muscle of seabass was mixed with $5 \mathrm{~mL}$ magnesium oxide $\left(10 \mathrm{~g} \cdot \mathrm{L}^{-1}\right)$, and then distilled using a Kjeldahl analyzer (Kjeltec8400, Foss, Denmark). The distillate was collected with $20 \mathrm{~mL}$ of boric acid solution $\left(0.02 \mathrm{~g} \cdot \mathrm{L}^{-1}\right)$ containing an indicator comprising methyl red and methylene blue. Then, the absorption solution was titrated with a $0.01 \mathrm{M}$ $\mathrm{HCl}$ solution. The TVB-N was expressed as milligrams of nitrogen per 100 grams of sea bass sample.

\subsection{Characterization of the Microbiota Based on Culture-Dependent Methods}

Compositions of microbiota were determined on days 0,12 , and 24 for all samples. Following total viable counts (TVC) counting, all colonies were isolated from the PCA (principal component analysis) plates that contained 30-100 colonies [41], cultivated in tryptic soy broth (TSB) at $30 \pm 1{ }^{\circ} \mathrm{C}$ for $24-36 \mathrm{~h}$, and then purified by scribing on a PCA plate. The purified communities were cultivated in TSB for additional multiplication, and then the cells were collected by centrifuging $2 \mathrm{~mL}$ of TSB culture. Bacterial DNA was extracted according to the procedure used for the Bacterial Genomic DNA Extraction Kit (Personal Biotechnology Co., Ltd., Shanghai, China). A fragment (about $1400 \mathrm{bp}$ ) of the 16S Ribosomal DNA (rRNA) bacterial gene was amplified using forward primer 27f (5'-GAGATTTGATCCTGGCTCAG-3') and reverse primer 1495r (5'CTACGGCTACCTTGTTACGA-3'). The details of the PCR reaction have been described previously [42]. PCR products were submitted to Biomed Biological Technology Co. Ltd. (Beijing, China) for sequencing. Preliminary identification was performed via a similarity search using the Eztaxon-e database (http:/ / www.eztaxon.org/) [43], where sequences with more than $97 \%$ identity were recognized as the same species. 


\subsection{Characterization of the Microbiota Based on Culture-Independent Methods}

\subsubsection{DNA Extraction and PCR Amplification}

The V3-V4 region of the bacteria's 16S rRNA genes were amplified via PCR using primers $338 \mathrm{f}$ (5'-barcode-ACTCCTACGGGAGGCAGCAG-3TC) and 907r (5AGGCAGCAG). PCR reactions were carried out in triplicate in a $20 \mu \mathrm{L}$ mixture containing $4 \mu \mathrm{L}$ of $5 \times$ FastPfu Buffer (Miozyme, Shanghai, China), $0.8 \mu \mathrm{L}$ of each primer $(5 \mu \mathrm{M}), 2 \mu \mathrm{L}$ of $2.5 \mathrm{mM}$ dNTPs, $0.4 \mu \mathrm{L}$ of FastPfu Polymerase, $10 \mathrm{ng}$ of template DNA, and double-distilled water. PCR amplicons were extracted from 2\% agarose gels and purified using the AxyPrep DNA Gel Extraction Kit (Axygen Biosciences, Union City, CA, USA) and they were quantified using QuantiFluor ${ }^{\text {TM_ST }}$ (Promega, Madison, WI, USA).

\subsubsection{Illumina MiSeq Sequencing and Data Processing}

Purified amplicons were pooled in equimolar amounts and they were paired-end sequenced $(2 \times 300 \mathrm{bp})$ on an Illumina MiSeq platform (Illumina Inc, San Diego, CA, USA). The raw reads were deposited into the NCBI Sequence Read Archive (SRA) database. Raw fastq files were demultiplexed and quality-filtered using QIIME (version 1.17). UPARSE was used to cluster the operation unit (OTU) with a similarity cut-off value of $97 \%$ (version 7.1, http://drive5.com/uparse/) [44] and chimeric sequences were identified and removed using UCHIME version 4.1. Based on the silva (SSU115) 16S rRNA database, each $16 \mathrm{~S}$ rRNA gene sequence was classified using RDP Classifier (http:/ /rdp.cme.msu.edu/) [45] with a credibility threshold of $70 \%$.

\subsection{Data Processing and Taxonomic Classification}

The raw sequencing data were analyzed and refined through the quality clinic process chart provided by the QIIME 1.6.0 software to ensure a greater degree of accuracy regarding OTU detection. Briefly, the final effective tags were obtained after the detection and removal of chimeric sequences.

OTUs defined by a $97 \%$ similarity were selected by applying the UPARSE software and the representative sequences were sent to RDP Classifier to get the taxonomy assignments on the levels of phylum, class, order, family, and genus, separately.

\subsection{Statistical Analysis}

Data of the TVB-N values were analyzed using SPSS 20.0 software and expressed as means \pm standard deviation. According to the results of the species annotation and their abundance information, the top 20 genera were picked out for the cluster analysis on microbial species. Fast-tree software (http:/ / www.microbesonline.org/fasttree) [36,46] and R-languages were used for the heat map drawing. The alpha diversity was evaluated through QIIME to generate Good's coverage, Chao1 richness, Simpson richness, Shannon diversity indices, and so on. The formulas used were as follows:

$$
S_{\mathrm{ACE}}=\left\{\begin{array}{l}
S_{\mathrm{abund}}+\frac{S_{\text {rare }}}{C_{\mathrm{ACE}}}+\frac{n_{1}}{C_{\mathrm{ACE}}} \hat{\gamma}_{\mathrm{ACE}}^{2}, \text { for } \hat{\gamma}_{\mathrm{ACE}}<0.80 \\
S_{\text {abund }}+\frac{S_{\mathrm{rare}}}{C_{\mathrm{ACE}}}+\frac{n_{1}}{C_{\mathrm{ACE}}} \widetilde{\gamma}_{\mathrm{ACE}}^{2} \text { for } \hat{\gamma}_{\mathrm{ACE}} \geq 0.80
\end{array}\right.
$$

In the formula,

$$
\begin{gathered}
N_{\text {rare }}=\sum_{i-1}^{\text {abund }} i n_{i}, C_{\mathrm{ACE}}=1-\frac{n_{1}}{N_{\text {rare }}} \\
\hat{\gamma}_{\mathrm{ACE}}^{2}=\max \left[\frac{S_{\text {rare }}}{C_{\mathrm{ACE}}} \frac{\sum_{i=1}^{\text {abund }} i(i-1) n_{i}}{N_{\text {rare }}\left(N_{\text {rare }}-1\right)}-1,0\right] \\
\widetilde{\gamma}_{\mathrm{ACE}}^{2}=\max \left[\hat{\gamma}_{\mathrm{ACE}}^{2}\left\{1+\frac{N_{\text {rare }}\left(1-C_{\mathrm{ACE}}\right) \sum_{i-1}^{\text {abund }} i(i-1) n_{i}}{N_{\text {rare }}\left(N_{\text {rare }}-C_{\mathrm{ACE}}\right)}\right\}, 0\right]
\end{gathered}
$$


where $n_{i}$ means the number of OTUs with $i$ sequences, $S_{\text {rare }}$ means the number of OTUs with "abund" or less sequences, $S_{\text {abund }}$ means the number of OTUs with more than "abund" sequences, and abund means the threshold value of OTU, which is 10 by default.

$$
S_{\text {chao } 1}=S_{\text {obs }}+\frac{n_{1}\left(n_{1}-1\right)}{2\left(n_{2}+1\right)}
$$

where $S_{\text {Chao1 }}$ means the Chao1 index, $S_{\text {obs }}$ means the number of OTUs, $n_{1}$ means the number of OTUs with only one sequence, and $n_{2}$ means the number of OTU with two sequences.

$$
H_{\text {shannon }}=-\sum_{i=1}^{S_{\text {obs }}} \frac{n_{i}}{N} \ln \frac{n_{i}}{N}
$$

where $H_{\text {shannon }}$ means the Shannon index, $n_{i}$ means the number of OTUs with a corresponding sequence, and $N$ means the number of sequences.

$$
D_{\text {simpson }}=\frac{\sum_{i=1}^{S_{\text {obs }}} n_{i}\left(n_{i}-1\right)}{N(N-1)}
$$

where $D_{\text {simpson }}$ means the Simpson index.

\section{Results and Discussions}

\subsection{TVB-N Values}

TVB-N is mainly comprised of ammonia, methylamine, dimethylamine, and trimethylamine, and is produced by the bacterial degradation of protein and non-protein nitrogen compounds [47]. TVB-N analysis has traditionally been used as an indicator of fish quality [48] and a value higher than $25 \mathrm{mg} \mathrm{N} / 100 \mathrm{~g}$ indicates that a fish is unfit for human consumption [49]. The changes in TVB-N values in the seabass fillets during cold $\left(-0.9^{\circ} \mathrm{C}\right)$ storage are displayed in Table 1 . The TVB-N values of seabass fillet samples on day 0 was $9.11 \mathrm{mg} \mathrm{N} / 100 \mathrm{~g}$, which indicates the good quality of the fish used in this study [50]. The TVB-N value in all samples increased slowly during the first 12 days of storage at $-0.9^{\circ} \mathrm{C}$. This was because the microorganisms need to acclimate to the new environment for a long time and the reproduction is slow [51]. In addition, due to the increase in endogenous enzymes and bacterial activity, the TVB-N values in all samples increased sharply on the 12th day [52].

Table 1. The total volatile basic nitrogen (TVB-N) value of seabass in different storage periods.

\begin{tabular}{cccccc}
\hline TVB-N (mg N/100 g) & CK & VP & G-0.075E + VP & G-0.15E + VP & G-0.30E + VP \\
\hline Time day & & & & & \\
\hline 12th day & $9.11 \pm 0.31$ & $9.11 \pm 0.31$ & $9.11 \pm 0.31$ & $9.11 \pm 0.31$ & $9.11 \pm 0.31$ \\
24th day & $13.24 \pm 0.44$ & $12.29 \pm 0.50$ & $11.84 \pm 0.29$ & $11.46 \pm 0.17$ & $11.08 \pm 0.30$ \\
& $26.61 \pm 0.60$ & $22.69 \pm 0.58$ & $19.73 \pm 0.41$ & $16.54 \pm 0.35$ & $14.28 \pm 0.37$ \\
\hline
\end{tabular}

CK: uncoated, VP: vacuum packaged, G-0.075E + VP: coated with the active gelatin coating containing $0.075 \%$ eugenol and vacuum packaged, G-0.15E + VP: coated with the active gelatin coating containing $0.15 \%$ eugenol and vacuum packaged, G-0.30E + VP: coated with the active gelatin coating containing $0.30 \%$ eugenol and vacuum packaged.

The TVB-N value of CK was higher than that of other samples and exceeded the upper limit on the 24th day $(p>0.01)$. However, the seabass fillet samples treated with vacuum packaging and the active gelatin coating containing eugenol were still below the limit at that time because eugenol possesses strong antimicrobial and antioxidant capacity [53]. The protective effect of eugenol and vacuum packing could inhibit the growth of Gramnegative aerobic bacteria (Pseudomonas spp. and $\mathrm{H}_{2} \mathrm{~S}$-producing bacteria), which produce volatile compounds [54]. The TVB-N values were decreased correspondingly for all treated seabass fillet samples during cold storage (Table 1), indicating that vacuum packaging 
delays the decomposition of proteins and nucleic acids into trimethylamine, amines, and other nitrogen-containing substances [55]. Meanwhile, the inhibition effect of the active gelatin coating containing eugenol on the growth of microorganisms increased linearly with the concentration of eugenol. The combination of vacuum packaging and the active gelatin coating containing eugenol blocked the contact between the seabass meat and air-oxidizable substances and delayed the degradation of proteins and nucleic acids by microorganisms. Similarly, Zhao et al. [56] indicated that tilapia fillets treated with a fish gelatin coating containing grape seed and then vacuum packaged could inhibit the growth of microorganisms and the increase of TVB-N values.

\subsection{Analysis of High-Throughput Sequencing Data}

The sequencing on the Illumina MiSeq platform resulted in 513,249 sequences: 44,432 sequences originated from all $0 \mathrm{~d}$ samples, 86,051 sequences from all CK samples, 101,213 sequences from all VP samples, 85,700 sequences from all G-0.075E + VP samples, 101,928 sequences from all G-0.15E + VP samples, and 93,925 sequences from all G-0.30E + VP samples (Table 2). The average length of these sequences was 426, 427, 427, 427 , and 427 bp for the CK, VP, G-0.075E + VP, G-0.15E + VP, and G-0.30E + VP samples, respectively. All these sequences were delineated into OTUs with a minimum sequence similarity threshold of $97 \%$. The coverage of all samples was $99.9 \%$, indicating that this level of sequencing identified almost all the bacterial phylotypes in the seabass samples (Table 2). Chao1 and ACE indicators provide other estimates of OTU richness, whose values were higher than the OTUs observed in each corresponding sample. The results showed that there might be a small number of microbial system types in all samples. The Shannon index reflects the diversity of a bacterial community; the highest Shannon indices were observed in CK on the 12th day. The species diversities of the other treatment samples decreased at first and then tended to be flat, indicating that the microbial communities in seabass treated with vacuum packaging and the active gelatin coating containing eugenol had lower bacterial diversities.

Table 2. Alpha diversity estimation of each sample.

\begin{tabular}{|c|c|c|c|c|c|c|c|c|c|}
\hline $\begin{array}{l}\text { Sample } \\
\text { Estimators }\end{array}$ & $\begin{array}{l}\text { Total } \\
\text { Tags }\end{array}$ & OTUs & $\begin{array}{l}\text { Average } \\
\text { Length }\end{array}$ & ACE & Chao1 & Coverage & Shannon & Simpson & $S_{\text {obs }}$ \\
\hline 0 day & $44,432.00$ & 146.70 & 424.00 & 236.20 & 239.20 & 1.00 & 2.93 & 0.11 & 229.00 \\
\hline 12th day CK & $40,338.00$ & 12.15 & 424.00 & 686.62 & 687.79 & 1.00 & 3.91 & 0.06 & 684.00 \\
\hline 24th day CK & $45,713.00$ & 6.57 & 429.00 & 44.99 & 37.50 & 1.00 & 0.85 & 0.62 & 30.00 \\
\hline 12th day VP & $50,269.00$ & 10.45 & 429.00 & 98.49 & 104.00 & 1.00 & 1.66 & 0.36 & 74.00 \\
\hline 24th day VP & $50,944.00$ & 6.00 & 429.00 & 48.18 & 67.00 & 1.00 & 1.76 & 0.22 & 39.00 \\
\hline $\begin{array}{c}\text { 12th day } \\
\text { G-0.075E + VP }\end{array}$ & $37,492.00$ & 35.68 & 427.00 & 223.20 & 222.12 & 1.00 & 2.15 & 0.29 & 220.00 \\
\hline $\begin{array}{c}\text { 12th day } \\
\text { G-0.15E + VP }\end{array}$ & $50,858.00$ & 22.22 & 429.00 & 148.84 & 159.20 & 1.00 & 1.02 & 0.46 & 134.00 \\
\hline $\begin{array}{c}\text { 12th day } \\
\text { G-0.30E + VP }\end{array}$ & $44,114.00$ & 15.61 & 429.00 & 119.78 & 85.77 & 1.00 & 1.39 & 0.39 & 68.00 \\
\hline $\begin{array}{c}\text { 24th day } \\
\text { G-0.075E + VP }\end{array}$ & $48,208.00$ & 8.85 & 429.00 & 110.16 & 99.12 & 1.00 & 1.24 & 0.41 & 89.00 \\
\hline $\begin{array}{c}\text { 24th day } \\
\text { G-0.15E + VP }\end{array}$ & $51,070.00$ & 7.93 & 429.00 & 106.28 & 84.25 & 1.00 & 1.52 & 0.28 & 46.00 \\
\hline $\begin{array}{c}\text { 24th day } \\
\text { G-0.30E + VP }\end{array}$ & $49,811.00$ & 7.11 & 429.00 & 56.68 & 46.25 & 1.00 & 1.50 & 0.37 & 41.00 \\
\hline
\end{tabular}

OTUs (operational taxonomic units).

Principal component analysis is commonly used to classify and cluster samples. At the genus level, the variation of bacterial diversity in the different samples was $63.15 \%$ (the first part PC, PC1 40.21\% and the second part PC, PC2 22.94\%, Figure 1), implying a good separation by region. An obvious region discrepancy between the vacuum packaging combined with the active gelatin coating containing eugenol and the CK samples revealed 
the different microbial communities, which may have been related to the antimicrobial activity of the active gelatin coating containing eugenol and the vacuum packaging.

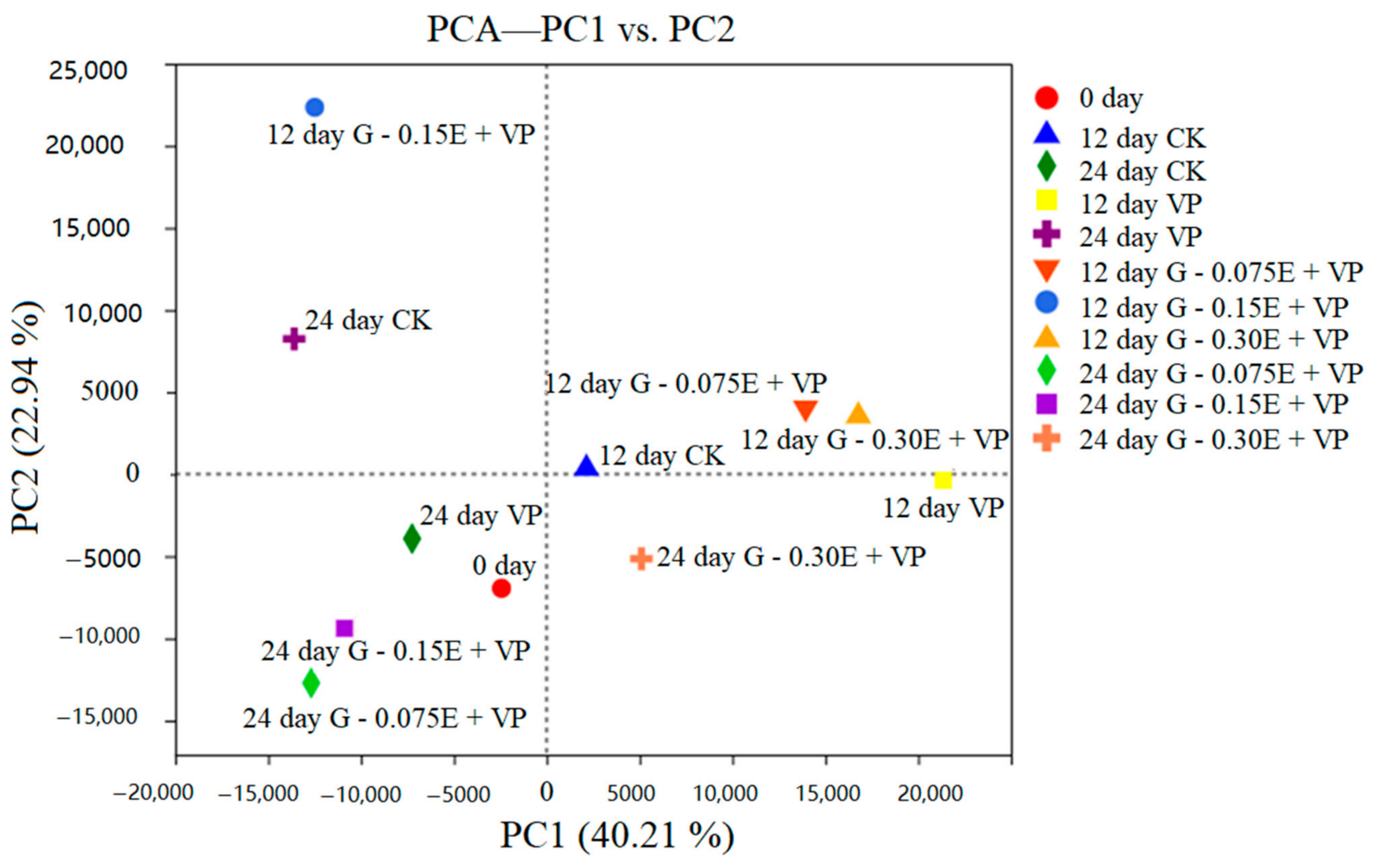

Figure 1. Results of principal component analysis at the genus level for each sample.

\subsection{Bacterial Diversity Analysis}

Figure 2 shows the rarefaction curve of the seabass fillet samples. The rarefaction curve is used to randomly select a certain number of individuals from the sample, count the number of species represented by these individuals, and construct the curve based on the number of individuals and species to evaluate whether the sequencing depth is sufficient $[57,58]$. Figure 2a shows the rarefaction curve of the $S_{\text {obs }}$ index, where its ordinate represents species number. The number of OTUs of the CK sample on the 12th day was the most, that is, the number of species was the most (Figure 2a). The number of OTUs in samples of G-0.075E + VP on 0 day and 12th day were similar, the curve finally flattened, indicating that there were enough sample readings to ensure the rationality of sequencing amount, and the sequencing depth almost covered all species information [59]. Figure $2 b$ shows the rarefaction curve of the Shannon index, whose ordinate represents the species diversity. The highest Shannon index samples were CK on 12th day, G-0.75E + VP on 0d, and 12th day. The species diversity of the CK sample first increased to the highest and then decreased to the lowest, while that of other samples decreased first and then tended to be flat, indicating that the vacuum packaging combined with the active gelatin coating containing eugenol inhibited the growth and reproduction of some bacteria and reduced the bacterial diversity. 


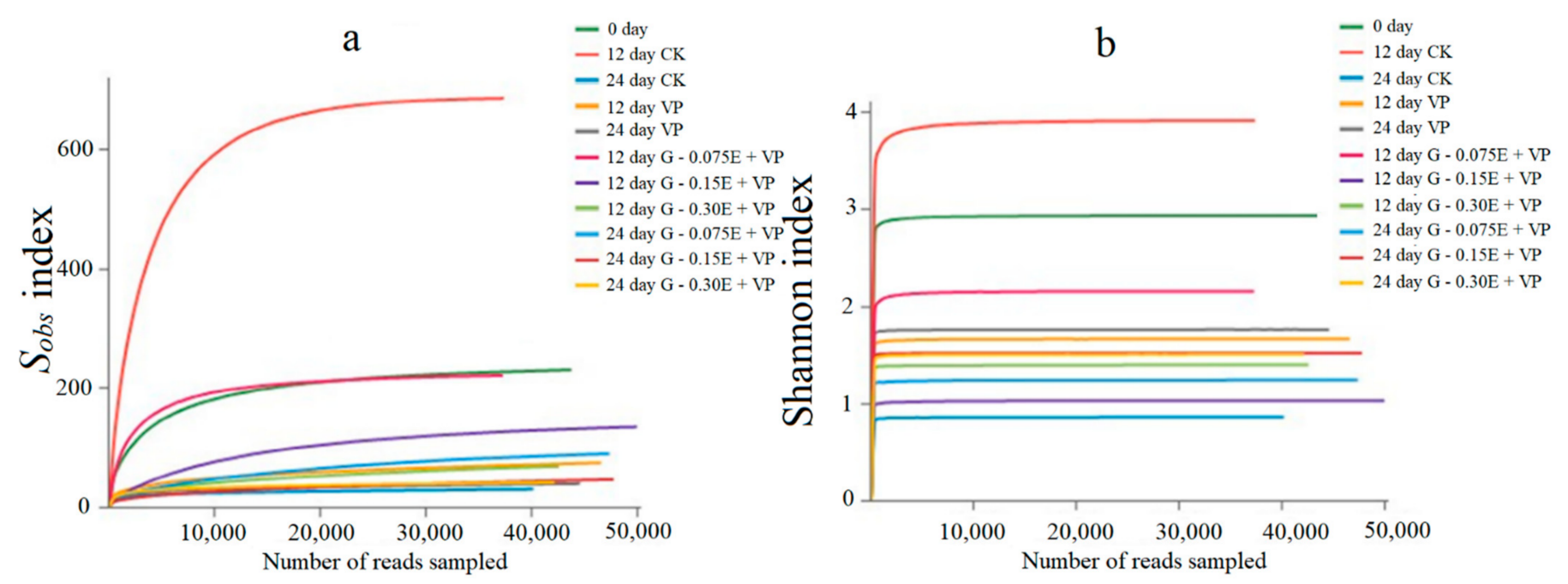

Figure 2. Rarefaction curve of each sample: (a) $S_{\text {obs }}$ index; (b) Shannon index.

\subsection{Analysis of the Species Community Composition}

High-throughput sequencing based on the Illumina MiSeq platform quantified the compositions and relative abundances of the bacterial communities in the seabass fillets during cold storage. The relative abundances of the top 19 genera in all samples at different times of storage are shown in Figure 3. With the increase in storage time, the bacterial diversity gradually decreased, which was consistent with the effect of glycooligosaccharide studied by Jia [60] on the microbial community of silver carp under cold storage. This is because the specific low-temperature environment and fish nutrients can promote the growth and reproduction of dominant putrefactive bacteria while inhibiting the growth of other bacteria [59]. Carnobacterium, Glutamicibacter, and Pseudomonas were the predominant bacterial genera (with abundance ratios of $0.286,0.160$, and 0.130 , respectively) in the seabass fillet samples on 0 day. With increased storage time, the dominance of Shewanella was most apparent (0.220) in the stored CK samples on the 12th day, followed by Pseudomonas (0.174). At the end of the seabass fillets' shelf life, Pseudomonas (0.802) dominated the microbiota of spoiled seabass fillets, which was significantly higher than that of other genera $(p>0.01)$, followed by Shewanella $(0.163)$. The same predominant bacterial phyla were also found in VP samples on the 24th day. Thus, Pseudomonas and Shewanella were the dominant spoilage bacteria during the low-temperature storage of seabass, which was similar to the effect of ethanolic coconut husk extract and modified atmospheric packaging (MAP) studied by Olatunde et al. [61] regarding the microbial community of Asian sea bass slices during storage at $4{ }^{\circ} \mathrm{C}$. The rapid propagation of Pseudomonas makes it decompose and utilize proteins. With the production of metabolic compounds (aldehydes, ketones, biogenic amines, volatile sulfides, etc.), the odor, texture, and flavor of seabass deteriorated rapidly [62].

In the VP samples on the 12th day, more than half of the sequences represented Brochothrix (58.2\% of the sequences), followed by the genus Macrococcus (11.9\% of the sequences), Shewanella (7.5\% of the sequences), Carnobacterium (7.4\% of the sequences), and Pseudomonas (5.9\% of the sequences) in the microbiota. Therefore, the vacuum treatment inhibited the growth of Shewanella and Pseudomonas. Höll et al. [63] also found that Brochothrix and Pseudomonas were the dominant spoilage bacteria in refrigerated chicken in a high-oxygen environment. When the storage time reached 24 days, the bacteria genera in the samples of seabass were mainly Pseudomonas, Shewanella, Carnobacterium, and Vagococcus, with abundance ratios of $0.343,0.279,0.204$, and 0.126 , respectively. Therefore, vacuum packaging could effectively inhibit the growth of the spoilage bacteria abundances in the seabass at low temperatures. $\mathrm{Li}$ et al. also came to a similar conclusion by analyzing the degree of putrefaction in packed yellow croaker pieces under a vacuum at $4{ }^{\circ} \mathrm{C}$ [64]. 


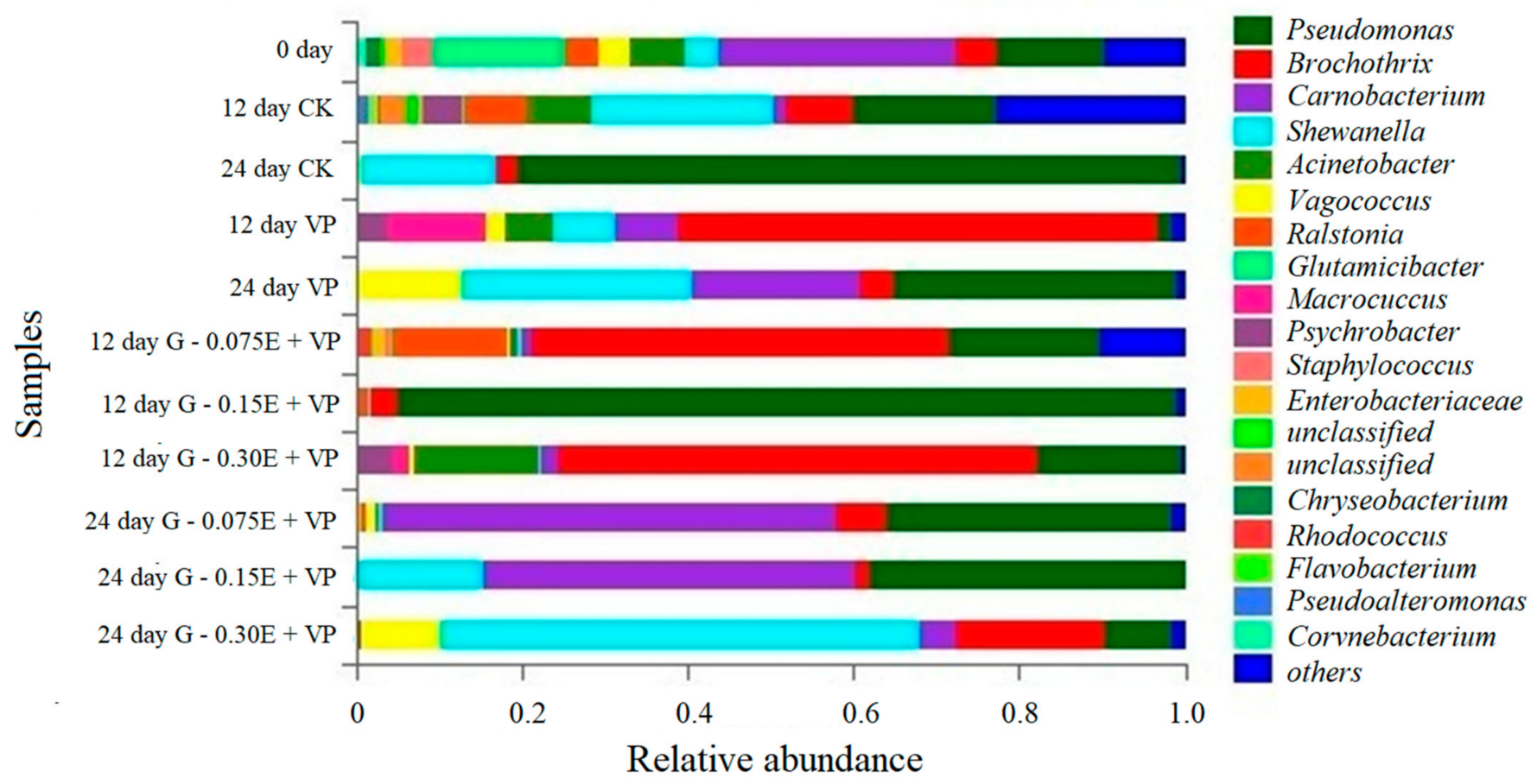

Figure 3. Relative abundances at the genus level based on the classification of partial 16S rRNA gene sequences of microbiota from various seabass fillet samples during cold storage.

The abundance ratios of the bacteria in the seabass samples after vacuum packaging combined with the active gelatin coating containing different concentrations of eugenol treatment showed great differences. The increase in eugenol concentration resulted in the decrease of the number of species of bacteria in the seabass, which may be attributed to the damage of some bacterial cell membranes caused by eugenol and the death of cells due to the leakage of internal solutes, such as protein and nucleic acid [65]. Therefore, a small number of bacteria with a weak resistance to eugenol will be killed by a high concentration of eugenol [66]. After the seabass fillet samples were stored for 24 days, the relative abundances of Pseudomonas in the G-0.075E + VP, G-0.15E + VP, and G-0.30E + VP samples were $0.343,0.379$, and 0.081 , respectively; the relative abundances of the Carnobacterium were $0.547,0.447$, and 0.044 , respectively; the relative abundances of Shewanella were 0.006 , 0.157 , and 0.579 , respectively. These results indicated that vacuum packaging combined with the active gelatin coating containing high concentrations of eugenol can effectively inhibit the growth of Pseudomonas and Carnobacterium. Without the rapid propagation of the competing genera, the abundance of Shewanella gradually increased and became the predominant bacterial genus. The facultative anaerobic Shewanella is a kind of bacteria that can utilize lactic acid in seafood as a carbon source to grow and reproduce and produce trimethylamine and the peculiar smelling dimethylamine. Hydrogen sulfide can be produced by Shewanella, Shewanella putrefaciens and Shewanella proteamaculans at low temperatures, which leads to the spoilage of marine products [67].

\subsection{Microbial Community Succession Heat Map}

In order to analyze and compare the compositions and dynamic changes of the bacterial communities in different seabass samples during cold storage, a heat map reflecting the relative abundances of the top 20 genera in all seabass samples for different storage periods was constructed (Figure 4). Among the top 20 genus-level phylotypes, the color intensity and the corresponding numbers are proportional to the relative abundances in each row of the heat map $[68,69]$. On 0 day, the predominant populations were Carnobacterium $(0.286)$, followed by Glutamicibacter (0.160), and Pseudomonas (0.130) in the seabass fillet samples. After the fillets were coated with the active gelatin coating containing eugenol and vacuum 
packaged, less diverse microbial communities were observed in the seabass fillets. In addition, more than half of the top 20 bacterial genera were relatively more abundant only in the CK samples on 0 and 12th day (Figure 4). The highest relative abundance was observed for genus Pseudomonas in G-0.15E + VP samples on the 12th day compared with that of other samples. At the end of storage, there was a lower diversity of genera in the seabass fillet samples. Although the bacterial genera in each sample were different due to different treatments, the main bacteria genera were Pseudomonas, Shewanella, Brochothrix, and Carnobacterium in the red aggregation area. Pseudomonas accounted for the largest proportion among them. These results were consistent with the results of the above analysis of species community compositions.

\section{Community heat map}

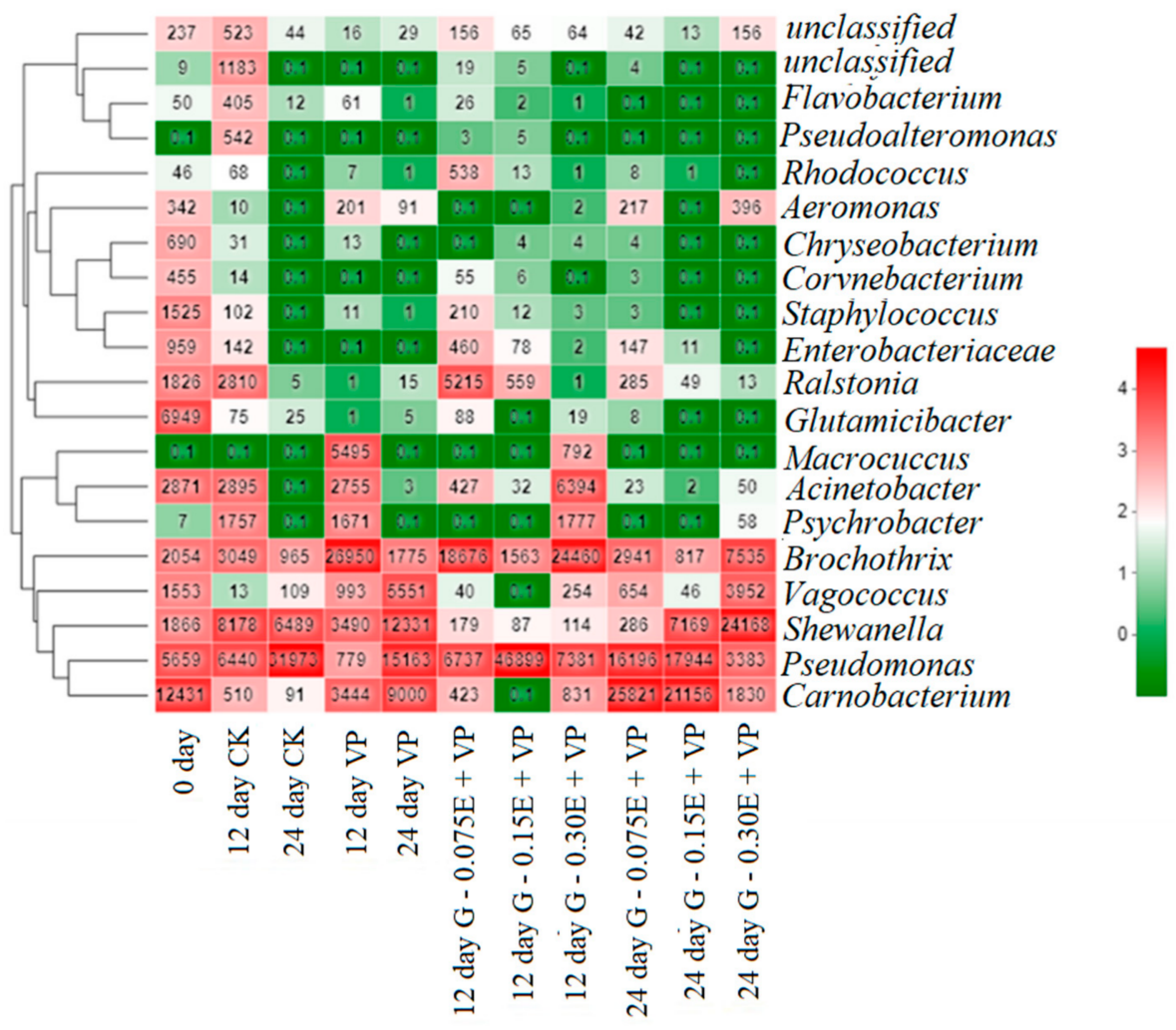

Figure 4. Relative abundance of microbiota at the genus level. Rows in the heat map represent different genus-level phylotypes, while columns represent different common carp samples. The color intensity is proportional to the abundance of OTUs in each row.

\subsection{Culture-Dependent Analyses of the Microbiota}

Fish spoilage is mainly due to microbial growth. A change in microbial diversity can lead to a change in fish spoilage mode and process. Therefore, it is necessary to characterize the composition of microbiota during fish cold storage, analyze the pattern and mechanisms of fish spoilage, and then target screening for effective food preservation techniques to maintain the quality during cold storage. Characterization of dominant bacteria in fish spoilage is the basis for analyzing the spoilage potential of these bacteria [47]. Thus, the microbiota composition of seabass fillets on 0,12 th, and 24 th day were analyzed in this study.

A total of 47 single colonies were isolated and purified on 0,12 th, and 24th day of five different treatment samples. Seventeen typical colonies were obtained after colony morphology observation, classification, and counting. The comparison results of the $16 \mathrm{~S}$ rDNA gene fragment sequencing are shown in Table 3. There were eight genera of bacteria, including nine species of Pseudomonas. The highest bacterial diversity was detected using culture-dependent methods in seabass fillet samples on 0 day (Table 4), 
which was consistent with the results of the analysis of the species community composition on 0 day. As the storage time progressed, the number of strains on the 12th day of each sample was greater than that on the 24th day, and the bacterial diversity gradually became lower with the growth and reproduction of dominant strains.

Table 3. The result of the sequence alignments of gene fragments.

\begin{tabular}{|c|c|c|c|c|}
\hline Number & & Results & Similarity & Accession No. \\
\hline 1 & Pseudomonas & Pseudomonas fragi & $99.58 \%$ & NR_024946.1 \\
\hline 2 & Pseudomonas & Pseudomonas lactis & $100.00 \%$ & NR_156986.1 \\
\hline 3 & Pseudomonas & Pseudomonas psychrophila & $99.31 \%$ & NR_028619.1 \\
\hline 4 & Brochothrix & Brochothrix thermosphacta & $100.00 \%$ & NR_113587.1 \\
\hline 5 & Pseudomonas & Pseudomonas migulae & $99.52 \%$ & NR_024927.1 \\
\hline 6 & Brachybacterium & $\begin{array}{c}\text { Brachybacterium } \\
\text { rhamnosum }\end{array}$ & $99.93 \%$ & NR_042109.1 \\
\hline 7 & Shewanella & Shewanella baltica & $98.57 \%$ & NR_025267.1 \\
\hline 8 & Pseudomonas & Pseudomonas libanensis & $99.51 \%$ & NR_024901.1 \\
\hline 9 & Pseudomonas & $\begin{array}{c}\text { Pseudomonas } \\
\text { weihenstephanensis }\end{array}$ & $99.31 \%$ & NR_148764.1 \\
\hline 10 & Pseudomonas & Pseudomonas helleri & $99.37 \%$ & NR_148763.1 \\
\hline 11 & Carnobacterium & Carnobacterium divergens & $99.45 \%$ & NR_113798.1 \\
\hline 12 & Pseudomonas & Pseudomonas veronii & $99.51 \%$ & NR_028706.1 \\
\hline 13 & Carnobacterium & $\begin{array}{l}\text { Carnobacterium } \\
\text { maltaromaticum }\end{array}$ & $98.31 \%$ & NR_044710.2 \\
\hline 14 & Agrobacterium & Agromyces indicus & $99.65 \%$ & NR_108908.1 \\
\hline 15 & Microbacterium & $\begin{array}{c}\text { Microbacterium } \\
\text { trichothecenolyticum }\end{array}$ & $98.72 \%$ & NR_044937.1 \\
\hline 16 & Pseudomonas & Pseudomonas paralactis & $99.86 \%$ & NR_156987.1 \\
\hline 17 & Staphylococcus & Staphylococcus edaphicus & $99.80 \%$ & NR_074999.2 \\
\hline
\end{tabular}

The bacterial diversity gradually became lower as the storage time progressed. There were four bacteria genera in the CK sample on the 12th day of storage, which reduced to only two bacteria genera on the 24th day, namely Pseudomonas and Shewanella. The results demonstrated that Pseudomonas and Shewanella were the dominant bacterial samples of the seabass fillets during the cold storage. Compared with the gelatin coating treatment sample containing different concentrations of eugenol, the VP sample had a higher species abundance. Microbacterium and Staphylococcus disappeared after the gelatin coating treatment with different concentrations of eugenol, which may have been due to the strong antimicrobial activity of eugenol against Microbacterium and Staphylococcus. Liu et al. and Ghosh et al. also found the excellent antimicrobial activity of eugenol against Staphylococcus aureus and Escherichia coli [70,71]. According to Figure 3, Staphylococcus grew and propagated fastest under vacuum packaging, accounting for $18.6 \%$ of the total bacterial abundance on the 24th day. Vacuum packaging can delay the growth of microorganisms by reducing the contact between the samples and oxygen, though facultative anaerobic or specific anaerobic Staphylococcus will have an advantage since it is easier to reproduce [72,73]. 
Table 4. Identification of bacteria isolated from various seabass fillet samples during cold storage at $-0.9^{\circ} \mathrm{C}$ using culture-dependent $16 \mathrm{~S}$ rRNA gene sequencing analysis.

\begin{tabular}{|c|c|c|c|c|c|c|c|c|c|c|c|c|c|c|c|c|c|c|c|c|c|}
\hline $\begin{array}{c}0 \mathrm{~d} \\
\text { Species } \\
\text { identifica- } \\
\text { tion }\end{array}$ & Number & $\begin{array}{c}\text { 12th day } \\
\text { CK } \\
\text { Species } \\
\text { identifica- } \\
\text { tion }\end{array}$ & Number & $\begin{array}{c}\text { 24th day } \\
\text { CK } \\
\text { Species } \\
\text { identifica- } \\
\text { tion }\end{array}$ & Number & $\begin{array}{l}\text { 12th day } \\
\text { VP } \\
\text { Species } \\
\text { identifica- } \\
\text { tion }\end{array}$ & Number & $\begin{array}{l}\text { 24th day } \\
\text { VP } \\
\text { Species } \\
\text { identifica- } \\
\text { tion }\end{array}$ & Number & $\begin{array}{l}\text { 12th day } \\
\text { G-0.075 } \\
\text { + VP } \\
\text { Species } \\
\text { identifica- } \\
\text { tion }\end{array}$ & Number & $\begin{array}{c}\text { 12th day } \\
\text { G-0.15E } \\
\text { VP } \\
\text { Species } \\
\text { identifica- } \\
\text { tion }\end{array}$ & Number & $\begin{array}{c}\text { 12th day } \\
\text { G-0.30E } \\
\text { VP } \\
\text { Species } \\
\text { identifica- } \\
\text { tion }\end{array}$ & Number & $\begin{array}{c}\text { 24th day } \\
\text { G-0.075 } \\
+ \text { VP } \\
\text { Species } \\
\text { identifica- } \\
\text { tion }\end{array}$ & Number & $\begin{array}{c}\text { 24th day } \\
\text { G-0.15E+ } \\
\text { VP } \\
\text { Species } \\
\text { identifica- } \\
\text { tion }\end{array}$ & Number & $\begin{array}{c}\text { 24th day } \\
\text { G-0.30E } \\
\text { VP } \\
\text { Species } \\
\text { identifica- } \\
\text { tion }\end{array}$ & Number \\
\hline Pseudomonas & 1 & Pseudomonas & 2 & Pseudomonas & 1 & $\begin{array}{l}\text { Pseudomonas } \\
\text { Shemorlhs }\end{array}$ & 5 & $\begin{array}{l}\text { Psendomonas } \\
\text { Shemomollh }\end{array}$ & 5 & $\begin{array}{l}P \text { Pseudomonas } \\
\text { Sheromons }\end{array}$ & 10 & Pseudomonas & 2 & Pseudomonas & 2 & Pseudomonas & 2 & Pseudomonas & 2 & Pseudomonas & 8 \\
\hline & $\begin{array}{c}5 \\
10\end{array}$ & Shewanella & $\begin{array}{c}16 \\
7\end{array}$ & 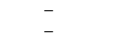 & $\frac{2}{3}$ & $\begin{array}{l}\text { Shevounella } \\
\text { Carrobatcerium }\end{array}$ & $\begin{array}{c}7 \\
11\end{array}$ & $\begin{array}{l}\text { Shervanella } \\
\text { Carrobacterium }\end{array}$ & $\begin{array}{c}7 \\
11\end{array}$ & $\begin{array}{l}\text { Shevonanella } \\
\text { Carrobacterium }\end{array}$ & $\begin{array}{c}7 \\
11\end{array}$ & - & $\begin{array}{l}8 \\
9\end{array}$ & - & $\begin{array}{l}10 \\
12\end{array}$ & Carnobacterium & $\begin{array}{c}8 \\
13\end{array}$ & 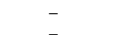 & $\begin{array}{l}8 \\
9\end{array}$ & Shewanella & ${ }_{7}^{12}$ \\
\hline Brochothrix & 4 & Brochothrix & 4 & - & 9 & Carnobacterium & $\begin{array}{l}11 \\
13 \\
13\end{array}$ & Carnobacterium & $\begin{array}{l}11 \\
13 \\
13\end{array}$ & $\begin{array}{l}\text { Carnoobacterumm } \\
\text { Brochothrix }\end{array}$ & $\begin{array}{l}11 \\
4\end{array}$ & - & 10 & Brochothrix & 4 & $\begin{array}{l}\text { Barnobacterium } \\
\text { Brochothrix }\end{array}$ & 4 & Shewanella & 7 & $\begin{array}{l}\text { Shevannella } \\
\text { Brochothrix }\end{array}$ & 4 \\
\hline Shewanella & 7 & Brachybacterium & & - & 10 & Brochothrix & 4 & Staphylococcus & 17 & Brachybacterium & 6 & Brochothrix & 4 & Carnobacterium & 11 & & & Carnobacterium & 11 & Carnobacterium & 13 \\
\hline Staphylococcus & 17 & - & - & Shewanella & 7 & Brachybacterium & 6 & Microbacterium & 15 & Agrobacterium & 14 & Carnobacterium & 11 & - & 13 & - & - & - & 13 & - & - \\
\hline Carnobacterium & $\begin{array}{l}11 \\
13\end{array}$ & $\begin{array}{l}- \\
\end{array}$ & 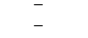 & - & $\overline{-}$ & $\begin{array}{l}\text { Microbacterrum } \\
\text { Staphylococcus }\end{array}$ & $\begin{array}{l}15 \\
17\end{array}$ & - & - & - & - & Brachybacterium & $\begin{array}{c}13 \\
6\end{array}$ & $\overline{-}$ & $\overline{-}$ & $\overline{-}$ & $\overline{-}$ & $\overline{-}$ & $\overline{-}$ & $\overline{-}$ & $\overline{-}$ \\
\hline $\begin{array}{l}\text { Microbacterium } \\
\text { Brachbuacterim }\end{array}$ & $\begin{array}{c}15 \\
6\end{array}$ & - & - & - & $\overline{-}$ & & & $\overline{-}$ & $\overline{-}$ & - & $\begin{array}{l}- \\
-\end{array}$ & & $\begin{array}{l}- \\
-\end{array}$ & $\overline{-}$ & $\overline{-}$ & $\overline{-}$ & $\overline{-}$ & $\overline{-}$ & $\overline{-}$ & - & $\overline{-}$ \\
\hline $\begin{array}{l}\text { Brachbacterium } \\
\text { Agrobacterium }\end{array}$ & $\begin{array}{l}6 \\
14\end{array}$ & - & - & - & - & & & - & - & - & - & & - & - & - & - & - & - & - & - & - \\
\hline
\end{tabular}


In the treatment using gelatin coatings containing eugenol after storage for 12 days, as the concentration of eugenol increased, the number of bacterial samples gradually decreased such that the concentration of eugenol was directly proportional to the antimicrobial effect. It can be inferred that the antimicrobial effect of eugenol on Agrobacterium was better than that on Brevibacterium. Shewanella was not detected in the high-concentration treatment sample, but it was detected on the 24th day. Combined with the analysis of the species community composition in Figure 3, it can be seen that eugenol had a strong inhibitory effect on Shewanella and Pseudomonas in the initial stage, while the inhibitory effect on Pseudomonas in the later stage was better than that of Shewanella. Vacuum packaging was responsible for hindering the growth of microorganisms through reducing the exposure of the sample to oxygen [74]. Moreover, eugenol had satisfactory antibacterial activity [75]. The results demonstrated that treatment with vacuum packaging combined with the active gelatin coating containing eugenol altered the composition of the microbiota in the seabass fillets, which caused the pattern and process of spoilage to change during cold storage.

\section{Conclusions}

As a preservative, eugenol has the potential to maintain good quality and to prolong the shelf life of seabass fillets during cold storage. Treatments with vacuum packaging combined with an active gelatin coating containing eugenol inhibited the naturally occurring microorganisms in seabass fillets and then altered the composition of the microbiota of seabass fillets, which modified their patterns and spoilage processes. Carnobacterium, followed by Glutamicibacter and Pseudomonas, were dominant in the spoiled seabass fillet samples. The abundance ratios of Pseudomonas and Shewanella increased from 0.220 and 0.174 on the 12 th day to 0.802 and 0.163 on the 24 th day, respectively. However, vacuum treatment also inhibited the growth of Shewanella and Pseudomonas. Brochothrix became the dominant bacteria in the middle of the storage period, while Pseudomonas and Shewanella dominated at the end of the storage period. In the active gelatin coating treatment with different concentrations of eugenol, with increasing concentrations of eugenol, the species abundances progressively decreased, the number of genera decreased, and the inhibitory effect on Pseudomonas and Carnobacterium gradually increased. Therefore, vacuum packaging combined with an active gelatin coating containing eugenol reduced the number of species of bacteria, inhibited the growth and reproduction of the main dominant spoilage bacteria, and delayed the spoilage of seabass. In addition, an unavoidable problem is that eugenol possesses an intense smell. Therefore, the use of eugenol may have some effect on the smell of fish. At present, the specific migration of eugenol and the effect of eugenol on the smell of fish fillets have not been studied. This will be a direction that will be investigated by researchers in the future.

Author Contributions: Conceptualization, X.M. and Q.Z.; methodology, W.Q.; software, J.M.; validation, X.M., Q.Z. and J.X.; formal analysis, X.M.; investigation, Q.Z.; resources, J.X.; data curation, Q.Z.; writing-original draft preparation, X.M.; writing—review and editing, X.M., Q.Z., and J.M.; visuali-zation, W.Q.; supervision, J.M.; project administration, J.X.; funding acquisition, J.X. All authors have read and agreed to the published version of the manuscript.

Funding: This research was funded by the China Agriculture Research System (CARS-47); the Shanghai Science and Technology Key Project on Agriculture from the Shanghai Municipal Agricultural Commission (2019-02-08-00-10-F01143); the National Key Research and Development Program (2016YFD0400106); and the Shanghai Science and Technology Commission Platform Capacity Construction Project (19DZ2284000).

Institutional Review Board Statement: Not applicable.

Informed Consent Statement: Not applicable.

Data Availability Statement: The data presented in this study are available in article. Data available in a publicly accessible repository.

Conflicts of Interest: The authors declare no conflict of interest. 


\section{References}

1. Wang, W.H.; Dong, H.B.; Sun, Y.X.; Cao, M.; Duan, Y.F.; Li, H.; Liu, Q.S.; Gu, Q.H.; Zhang, J.S. The efficacy of eugenol and tricaine methanesulphonate as anaesthetics for juvenile Chinese sea bass (Lateolabrax maculatus) during simulated transport. J. Appl. Ichthyol. 2019, 35, 551-557. [CrossRef]

2. Chaijan, S.; Panpipat, W.; Panya, A.; Cheong, L.Z.; Chaijan, M. Preservation of chilled Asian sea bass (Lates calcarifer) steak by whey protein isolate coating containing polyphenol extract from ginger, lemongrass, or green tea. Food Control 2020, 118, 107400. [CrossRef]

3. Martínez, O.; Salmerón, J.; Epelde, L.; Vicente, M.S.; de Vega, C. Quality enhancement of smoked sea bass (Dicentrarchus labrax) fillets by adding resveratrol and coating with chitosan and alginate edible films. Food Control 2018, 85, 168-176. [CrossRef]

4. Cai, L.; Cao, A.; Bai, F.; Li, J. Effect of $\varepsilon$-polylysine in combination with alginate coating treatment on physicochemical and microbial characteristics of Japanese sea bass (Lateolabrax japonicas) during refrigerated storage. LWT Food Sci. Technol. 2015, 62, 1053-1059. [CrossRef]

5. Teixeira, B.; Fidalgo, L.G.; Mendes, R.; Costa, G.D.; Cordeiro, C.; Marques, A.; Saraiva, J.A.; Nunes, M.L. Effect of high pressure processing in the quality of sea bass (Dicentrarchus labrax) fillets: Pressurization rate, pressure level and holding time. Innov. Food Sci. Emerg. Technol. 2014, 22, 31-39. [CrossRef]

6. Qiu, X.; Chen, S.; Liu, G.; Yang, Q. Quality enhancement in the Japanese sea bass (Lateolabrax japonicas) fillets stored at $4{ }^{\circ} \mathrm{C}$ by chitosan coating incorporated with citric acid or licorice extract. Food Chem. 2014, 162, 156-160. [CrossRef]

7. Sun, L.; Sun, J.; Thavaraj, P.; Yang, X.; Guo, Y. Effects of thinned young apple polyphenols on the quality of grass carp (Ctenopharyngodon idellus) surimi during cold storage. Food Chem. 2017, 224, 372-381. [CrossRef]

8. Zhang, Y.; Li, D.; Lv, J.; Li, Q.; Kong, C.; Luo, Y. Effect of cinnamon essential oil on bacterial diversity and shelf-life in vacuumpackaged common carp (Cyprinus carpio) during refrigerated storage. Int. J. Food Microbiol. 2017, 249, 1-8. [CrossRef]

9. Yu, D.; Wu, L.; Regenstein, J.; Jiang, Q.; Yang, F.; Xu, Y.; Xia, W. Recent advances in quality retention of non-frozen fish and fishery products: A review. Crit. Rev. Food Sci. Nutr. 2019, 60, 1-13. [CrossRef]

10. Carrión-Granda, X.; Fernández-Pan, I.; Rovira, J.; Maté, J. Effect of antimicrobial edible coatings and modified atmosphere packaging on the microbiological quality of cold stored hake (Merluccius merluccius) fillets. J. Food Qual. 2018, 2018, 1-12. [CrossRef]

11. Zhao, J.; Lv, W.; Wang, J.; Li, J.; Liu, X.; Zhu, J. Effects of tea polyphenols on the post-mortem integrity of large yellow croaker (Pseudosciaena crocea) fillet proteins. Food Chem. 2013, 141, 2666-2674. [CrossRef] [PubMed]

12. Alotaibi, S.; Tahergorabi, R. Development of a sweet potato starch-based coating and its effect on quality attributes of shrimp during refrigerated storage. LWT Food Sci. Technol. 2018, 88, 203-209. [CrossRef]

13. Alparslan, Y.; Baygar, T.N. Effect of chitosan film coating combined with orange peel essential oil on the shelf life of deepwater pink shrimp. Food Bioprocess. Technol. 2017, 10, 842-853. [CrossRef]

14. Alparslan, Y.; Yapici, H.H.; Metin, C.; Baygar, T.; Gunlu, A.; Baygar, T. Quality assessment of shrimps preserved with orange leaf essential oil incorporated gelatin. LWT Food Sci. Technol. 2016, 72, 457-466. [CrossRef]

15. Nilsuwan, K.; Benjakul, S.; Prodpran, T.; Caba, K.D.I. Fish gelatin monolayer and bilayer films incorporated with epigallocatechin gallate: Properties and their use as pouches for storage of chicken skin oil. Food Hydrocoll. 2019, 89, 783-791. [CrossRef]

16. Nilsuwan, K.; Guerrero, P.; Caba, K.D.I.; Benjakul, S.; Prodpran, T. Properties and application of bilayer films based on poly (lactic acid) and fish gelatin containing epigallocatechin gallate fabricated by thermo-compression molding. Food Hydrocoll. 2020, 105, 105792. [CrossRef]

17. Suderman, N.; Isa, M.I.N.; Sarbon, N.M. The effect of plasticizers on the functional properties of biodegradable gelatin-based film: A review. Food Biosci. 2018, 24, 111-119. [CrossRef]

18. Kan, J.; Liu, J.; Yong, H.; Liu, Y.; Qin, Y.; Liu, J. Development of active packaging based on chitosan-gelatin blend films functionalized with Chinese hawthorn (Crataegus pinnatifida) fruit extract. Int. J. Biol. Macromol. 2019, 140, 384-392. [CrossRef]

19. Staroszczyk, H.; Kusznierewicz, B.; Malinowska-Pańczyk, E.; Sinkiewicz, I.; Gottfried, K.; Kołodziejska, I. Fish gelatin films containing aqueous extracts from phenolic-rich fruit pomace. LWT Food Sci. Technol. 2020, 117, 108613. [CrossRef]

20. Yeddes, W.; Djebali, K.; Wannes, W.A.; Horchani-Naifer, K.; Hammami, M.; Younes, I.; Tounsi, M.S. Gelatin-chitosan-pectin films incorporated with rosemary essential oil: Optimized formulation using mixture design and response surface methodology. Int. J. Biol. Macromol. 2020, 154, 92-103. [CrossRef]

21. Jamróz, E.; Juszczak, L.; Kucharek, M. Investigation of the physical properties, antioxidant and antimicrobial activity of ternary potato starch-furcellaran-gelatin films incorporated with lavender essential oil. Int. J. Biol. Macromol. 2018, 114, $1094-1101$. [CrossRef] [PubMed]

22. Bermúdez-Oria, A.; Rodríguez-Gutiérrez, G.; Vioque, B.; Rubio-Senent, F.; Fernández-Bolaños, J. Physical and functional properties of pectin-fish gelatin films containing the olive phenols hydroxytyrosol and 3,4-dihydroxyphenylglycol. Carbohydr. Polym. 2017, 178, 368-377. [CrossRef] [PubMed]

23. Roy, S.; Rhim, J.W. Preparation of antimicrobial and antioxidant gelatin/curcumin composite films for active food packaging application. Colloids Surf. B 2020, 188, 110761. [CrossRef] [PubMed]

24. Neira, L.M.; Martucci, J.F.; Stejskal, N.; Ruseckaite, R.A. Time-dependent evolution of properties of fish gelatin edible films enriched with carvacrol during storage. Food Hydrocoll. 2019, 94, 304-310. [CrossRef]

25. Ashrafudoulla, M.; Mizan, M.F.R.; Ha, A.J.; Park, S.H.; Ha, S.D. Antibacterial and antibiofilm mechanism of eugenol against antibiotic resistance Vibrio parahaemolyticus. Food Microbiol. 2020, 91, 103500. [CrossRef] 
26. Qian, W.; Sun, Z.; Wang, T.; Yang, M.; Liu, M.; Zhang, J.; Li, Y. Antimicrobial activity of eugenol against carbapenem-resistant Klebsiella pneumoniae and its effect on biofilms. Microb. Pathog. 2020, 139, 103924. [CrossRef]

27. Wang, Q.; Zhang, L.; Ding, W. Eugenol nanocapsules embedded with gelatin-chitosan for chilled pork preservation. Int. J. Biol. Macromol. 2020, 158, 837-844. [CrossRef]

28. Cai, L.; Dai, Y.; Cao, A.; Cao, M. The effects of $\mathrm{CS} @ \mathrm{Fe}_{3} \mathrm{O}_{4}$ nanoparticles combined with microwave or far infrared thawing on microbial diversity of red seabream (Pagrus major) fillets based on high-throughput sequencing. Food Microbiol. 2020, 91, 103511. [CrossRef]

29. Jagadeesan, B.; Gerner-Smidt, P.; Allard, M.W.; Leuillet, S.; Winkler, A.; Xiao, Y.; Chaffron, S.; Vossen, J.V.D.; Tang, S.; Katase, M.; et al. The use of next generation sequencing for improving food safety: Translation into practice. Food Microbiol. 2019, 79, 96-115. [CrossRef]

30. Parlapani, F.F.; Michailidou, S.; Pasentsis, K.; Argiriou, A.; Krey, G.; Boziaris, I.S. A meta-barcoding approach to assess and compare the storage temperature-dependent bacterial diversity of gilt-head sea bream (Sparus aurata) originating from fish farms from two geographically distinct areas of Greece. Int. J. Food Microbiol. 2018, 278, 36-43. [CrossRef]

31. Huang, H.; Sun, W.; Xiong, G.; Shi, L.; Jiao, C.; Wu, W.; Li, X.; Qiao, Y.; Liao, L.; Ding, A.; et al. Effects of HVEF treatment on microbial communities and physicochemical properties of catfish fillets during chilled storage. LWT Food Sci. Technol. 2020, 131, 109667. [CrossRef]

32. Huang, Z.; Liu, X.; Jia, S.; Zhang, L.; Luo, Y. The effect of essential oils on microbial composition and quality of grass carp (Ctenopharyngodon idellus) fillets during chilled storage. Int. J. Food Microbiol. 2018, 266, 52-59. [CrossRef] [PubMed]

33. Balti, R.; Mansour, M.B.; Zayoud, N.; Balc'h, R.L.; Brodu, N.; Arhaliass, A.; Massé, A. Active exopolysaccharides based edible coatings enriched with red seaweed (Gracilaria gracilis) extract to improve shrimp preservation during refrigerated storage. Food Biosci. 2020, 34, 100522. [CrossRef]

34. Jia, S.; Huang, Z.; Lei, Y.; Zhang, L.; Li, Y.; Luo, Y. Application of Illumina-MiSeq high throughput sequencing and culturedependent techniques for the identification of microbiota of silver carp (Hypophthalmichthys molitrix) treated by tea polyphenols. Food Microbiol. 2018, 76, 52-61. [CrossRef]

35. Zang, J.; Xu, Y.; Xia, W.; Yu, D.; Gao, P.; Jiang, Q.; Yang, F. Dynamics and diversity of microbial community succession during fermentation of Suan yu, a Chinese traditional fermented fish, determined by high throughput sequencing. Food Res. Int. 2018, 111, 565-573. [CrossRef]

36. Rong, C.; Ling, Z.; Huihui, S.; Qi, L. Characterization of microbial community in high-pressure treated oysters by high-throughput sequencing technology. Innov. Food Sci. Emerg. Technol. 2018, 45, 241-248. [CrossRef]

37. Zhou, Q.; Li, P.; Fang, S.; Mei, J.; Xie, J. Preservative effects of gelatin active coating containing eugenol and higher $\mathrm{CO}_{2}$ concentration modified atmosphere packaging on Chinese sea bass (Lateolabrax maculatus) during superchilling $\left(-0.9^{\circ} \mathrm{C}\right)$ storage. Molecules 2020, 25, 871. [CrossRef]

38. Zhou, Q.; Li, P.; Fang, S.; Liu, W.; Mei, J.; Xie, J. Preservative effects of gelatin active coating enriched with eugenol emulsion on Chinese seabass (Lateolabrax maculatus) during superchilling $\left(-0.9^{\circ} \mathrm{C}\right)$ storage. Coatings 2019, 9, 489. [CrossRef]

39. Sun, X.; Guo, X.; Ji, M.; Wu, J.; Zhu, W.; Wang, J.; Cheng, C.; Chen, L.; Zhang, Q. Preservative effects of fish gelatin coating enriched with CUR/ $\beta C D$ emulsion on grass carp (Ctenopharyngodon idellus) fillets during storage at $4{ }^{\circ} \mathrm{C}$. Food Chem. 2019, 272, 643-652. [CrossRef]

40. Wang, W.; Li, M.; Li, H.; Liu, X.; Guo, T.; Zhang, G.; Xiong, Y. A renewable intelligent colorimetric indicator based on polyaniline for detecting freshness of tilapia. Packag. Technol. Sci. 2018, 31, 133-140. [CrossRef]

41. Liu, X.; Li, D.; Li, K.; Luo, Y. Monitoring bacterial communities in $\varepsilon$-Polylysine-treated bighead carp (Aristichthys nobilis) fillets using culture-dependent and culture-independent techniques. Food Microbiol. 2018, 76, 257-266. [CrossRef] [PubMed]

42. Liu, X.; Zhang, Y.; Li, D.; Luo, Y. Characterization of the microbiota in lightly salted bighead carp (Aristichthys nobilis) fillets stored at $4{ }^{\circ}$ C. Food Microbiol. 2017, 62, 106-111. [CrossRef] [PubMed]

43. EzBioCloud Database Home Page. Available online: http://www.eztaxon.org (accessed on 28 January 2021).

44. UPARSE OTU Clustering. Available online: http:/ / drive5.com/uparse (accessed on 28 January 2021).

45. RDP Classifier Home Page. Available online: http:/ / rdp.cme.msu.edu/ (accessed on 28 January 2021).

46. Fast Tree-Comparison Tools. Available online: http:/ / www.microbesonline.org/fasttree (accessed on 28 January 2021).

47. Liu, X.; Huang, Z.; Jia, S.; Zhang, J.; Li, K.; Luo, Y. The roles of bacteria in the biochemical changes of chill-stored bighead carp (Aristichthys nobilis): Proteins degradation, biogenic amines accumulation, volatiles production, and nucleotides catabolism. Food Chem. 2018, 255, 174-181. [CrossRef] [PubMed]

48. Aponte, M.; Anastasio, A.; Marrone, R.; Mercogliano, R.; Peruzy, M.F.; Murru, N. Impact of gaseous ozone coupled to passive refrigeration system to maximize shelf-life and quality of four different fresh fish products. LWT Food Sci. Technol. 2018, 93, 412-419. [CrossRef]

49. Ojagh, S.M.; Rezaei, M.; Razavi, S.H.; Hosseini, S.M.H. Effect of chitosan coatings enriched with cinnamon oil on the quality of refrigerated rainbow trout. Food Chem. 2010, 120, 193-198. [CrossRef]

50. Cai, L.; Wu, X.; Li, X.; Zhong, K.; Li, Y.; Li, J. Effects of different freezing treatments on physicochemical responses and microbial characteristics of Japanese sea bass (Lateolabrax japonicas) fillets during refrigerated storage. LWT Food Sci. Technol. 2014, 59, 122-129. [CrossRef] 
51. Mallon, C.A.; Elsas, J.D.V.; Salles, J.F. Microbial invasions: The process, patterns, and mechanisms. Trends Microbiol. 2015, 23, 719-729. [CrossRef]

52. Li, P.; Peng, Y.; Mei, J.; Xie, J. Effects of microencapsulated eugenol emulsions on microbiological, chemical and organoleptic qualities of farmed Japanese sea bass (Lateolabrax japonicus) during cold storage. LWT Food Sci. Technol. 2020, 118, 108831. [CrossRef]

53. Zheng, K.; Xiao, S.; Li, W.; Wang, W.; Chen, H.; Yang, F.; Qin, C. Chitosan-acorn starch-eugenol edible film: Physico-chemical, barrier, antimicrobial, antioxidant and structural properties. Int. J. Biol. Macromol. 2019, 135, 344-352. [CrossRef]

54. Veeck, A.P.D.L.; Daniel, A.P.; Klein, B.; Quatrin, A.; Rezer, A.P.D.S.; Milani, L.I.G.; Zeppenfeld, C.C.; Cunha, M.A.D.; Heldwein, C.G.; Heinzmann, B.M. Chemical, microbiological, and sensory parameters during the refrigerated storage of silver catfish (Rhamdia quelen) exposed in vivo to the essential oil of Lippia alba. J. Food Sci. Technol. 2018, 55, 1416-1425. [CrossRef]

55. Volpe, M.G.; Siano, F.; Paolucci, M.; Sacco, A.; Sorrentino, A.; Malinconico, M.; Varricchio, E. Active edible coating effectiveness in shelf-life enhancement of trout (Oncorhynchusmykiss) fillets. LWT Food Sci. Technol. 2015, 60, 615-622. [CrossRef]

56. Zhao, X.; Wu, J.E.; Chen, L.; Yang, H. Effect of vacuum impregnated fish gelatin and grape seed extract on metabolite profiles of tilapia (Oreochromis niloticus) fillets during storage. Food Chem. 2019, 293, 418-428. [CrossRef] [PubMed]

57. Mukherjee, A.; Rodiles, A.; Merrifield, D.L.; Chandra, G.; Ghosh, K. Exploring intestinal microbiome composition in three Indian major carps under polyculture system: A high-throughput sequencing based approach. Aquaculture 2020, 524, 735206. [CrossRef]

58. Huyben, D.; Vidaković, A.; Werner Hallgren, S.; Langeland, M. High-throughput sequencing of gut microbiota in rainbow trout (Oncorhynchus mykiss) fed larval and pre-pupae stages of black soldier fly (Hermetia illucens). Aquaculture 2019, 500, 485-491. [CrossRef]

59. Odeyemi, O.A.; Burke, C.M.; Bolch, C.C.J.; Stanley, R. Spoilage microbial community profiling by $16 \mathrm{~S}$ rRNA amplicon sequencing of modified atmosphere packaged live mussels stored at $4{ }^{\circ} \mathrm{C}$. Food Res. Int. 2019, 121, 568-576. [CrossRef]

60. Jia, S.; Liu, X.; Huang, Z.; Li, Y.; Zhang, L.; Luo, Y. Effects of chitosan oligosaccharides on microbiota composition of silver carp (Hypophthalmichthys molitrix) determined by culture-dependent and independent methods during chilled storage. Int. J. Food Microbiol. 2018, 268, 81-91. [CrossRef]

61. Olatunde, O.O.; Benjakul, S.; Vongkamjan, K. Combined effect of ethanolic coconut husk extract and modified atmospheric packaging (MAP) in extending the shelf life of asian sea bass slices. J. Aquat. Food Prod. Technol. 2019, 28, 689-702. [CrossRef]

62. Singh, S.; Lee, M.; Gaikwad, K.K.; Lee, Y.S. Antibacterial and amine scavenging properties of silver-silica composite for postharvest storage of fresh fish. Food Bioprod. Process. 2018, 107, 61-69. [CrossRef]

63. Höll, L.; Behr, J.; Vogel, R.F. Identification and growth dynamics of meat spoilage microorganisms in modified atmosphere packaged poultry meat by MALDI-TOF MS. Food Microbiol. 2016, 60, 84-91. [CrossRef]

64. Li, Y.; Huang, J.; Yuan, C.; Ding, T.; Chen, S.; Hu, Y. Developing a new spoilage potential algorithm and identifying spoilage volatiles in small yellow croaker (Larimichthys polyactis) under vacuum packaging condition. LWT Food Sci. Technol. 2019, 106, 209-217. [CrossRef]

65. Jeyakumar, G.E.; Lawrence, R. Mechanisms of bactericidal action of Eugenol against Escherichia coli. J. Herb. Med. 2020, in press. [CrossRef]

66. Zhang, Y.; Wang, Y.; Zhu, X.; Cao, P.; Wei, S.; Lu, Y. Antibacterial and antibiofilm activities of eugenol from essential oil of Syzygium aromaticum (L.) Merr. \& L. M. Perry (clove) leaf against periodontal pathogen Porphyromonas gingivalis. Microb. Pathog. 2017, 113, 396-402. [PubMed]

67. Odeyemi, O.A.; Burke, C.M.; Bolch, C.C.J.; Stanley, R. Seafood spoilage microbiota and associated volatile organic compounds at different storage temperatures and packaging conditions. Int. J. Food Microbiol. 2018, 280, 87-99. [CrossRef] [PubMed]

68. Mallappa, R.H.; Singh, D.K.; Rokana, N.; Pradhan, D.; Batish, V.K.; Grover, S. Screening and selection of probiotic Lactobacillus strains of Indian gut origin based on assessment of desired probiotic attributes combined with principal component and heatmap analysis. LWT Food Sci. Technol. 2019, 105, 272-281. [CrossRef]

69. Huang, Z.; Liu, X.; Jia, S.; Luo, Y. Antimicrobial effects of cinnamon bark oil on microbial composition and quality of grass carp (Ctenopharyngodon idellus) fillets during chilled storage. Food Control 2017, 82, 316-324. [CrossRef]

70. Liu, M.; Liu, Y.; Cao, M.J.; Liu, G.M.; Chen, Q.; Sun, L.; Chen, H. Antibacterial activity and mechanisms of depolymerized fucoidans isolated from Laminaria japonica. Carbohydr. Polym. 2017, 172, 294-305. [CrossRef]

71. Ghosh, V.; Mukherjee, A.; Chandrasekaran, N. Ultrasonic emulsification of food-grade nanoemulsion formulation and evaluation of its bactericidal activity. Ultrason. Sonochem. 2013, 20, 338-344. [CrossRef] [PubMed]

72. Sangare, L.; Chen, W.B.; Wang, C.L.; Chen, X.B.; Wu, M.H.; Zhang, X.; Zang, J.Y. Structural insights into the conformational change of Staphylococcus aureus NreA at C-terminus. Biotechnol. Lett. 2020, 42, 787-795. [CrossRef]

73. Baptista, R.F.; Lemos, M.; Teixeira, C.E.; Vital, H.C.; Carneiro, C.S.; Mársico, E.T.; Conte, C.A.; Mano, S.B. Microbiological quality and biogenic amines in ready-to-eat grilled chicken fillets under vacuum packing, freezing, and high-dose irradiation. Poult. Sci. 2014, 93, 1571-1577. [CrossRef]

74. Silbande, A.; Adenet, S.; Chopin, C.; Cornet, J.; Smith-Ravin, J.; Rochefort, K.; Leroi, F. Effect of vacuum and modified atmosphere packaging on the microbiological, chemical and sensory properties of tropical red drum (Sciaenops ocellatus) fillets stored at $4{ }^{\circ} \mathrm{C}$. Int. J. Food Microbiol. 2018, 266, 31-41. [CrossRef]

75. Zhao, R.; Rong, S.; Sun, G.; Liu, S.; Li, B.; Cao, Y.; Li, Y. Cutoff Ostwald ripening stability of eugenol-in-water emulsion by co-stabilization method and antibacterial activity evaluation. Food Hydrocoll. 2020, 107, 105925. [CrossRef] 